\title{
Identifying Peat Soil Layers in the South Kalimantan, Indonesia Using K-Means Clustering
}

\author{
Mimin Iryanti ${ }^{1 *}$, Ahmad Aminudin ${ }^{1}$, Eleonora Agustine ${ }^{2}$, Satria Bijaksana ${ }^{3}$, Wahyu Srigutomo ${ }^{4}$, \\ and Tedy Setiawan ${ }^{3}$ \\ 1 Faculty of Mathematics and Sciences Education, Universitas Pendidikan Indonesia; mien iryanti@upi.edu; \\ http://orcid.org/0000-0003-4037-9302 \\ 2 Faculty of Mathematics and Natural Sciences, Universitas Padjadjaran; leo@geophys.unpad.ac.id; \\ 3 Faculty of Mining and Petroleum Engineering, Institut Teknologi Bandung; satria@fi.itb.ac.id; \\ http://orcid.org/0000-0001-6374-4128 \\ 4 Faculty of Mathematics and Natural Sciences, Institut Teknologi Bandung; wahyu@fi.itb.ac.id; \\ http://orcid.org/0000-0001-6483-2410 \\ * Correspondence: mien_iryanti@upi.edu; Tel.: +62-812-215-24208
}

\begin{abstract}
Various type of soils have been identified based on their electrical and magnetic properties, especially with regards to peat soils. Peat soils are commonly considered as partly decomposed vegetation. In this study, electrical and magnetic properties have been used in K-means clustering to identify layers of peat soils. K-means clustering is a partitioning method that treats observations in the data. Data cores were obtained at every centimeter and examined for their electrical conductivity $(\sigma)$ and magnetic susceptibility $\left(\chi_{\mathrm{m}}\right)$ properties. A $291 \mathrm{~cm}$ core was obtained at Tegal Arum Village in South Kalimantan, Indonesia. The K-means clustering results indicate two different layers at $148 \mathrm{~cm}$, and this is supported by loss on ignition (LOI) measurements. In the first layers, a $87.65 \%$ LOI was found associated with peat soils (above 248 $\mathrm{cm}$ ). Whereas, in the second layers, there was a $26.11 \%$ LOI associated with mineral soils (below $248 \mathrm{~cm}$ ). The results of this study using K-means clustering can be used to delineate soil layers.
\end{abstract}

Keywords: peat; electrical conductivity; magnetic susceptibility; K-means clustering; loss on ignition (LOI); organic soils; mineral soils; Indonesia

\section{Introduction}

The study of peat soil has developed rapidly to be able to determine carbon emissions, especially in the peatlands of Indonesia [1-7]. A large amount of carbon emission is produced by peatlands, which is mostly determined by the depth or the thickness of the peat $[1,2,8]$. Accurate information parameters on the depth and the thickness of the peat must be used in this research. Determination of depth or thickness of peat soil is usually done by direct measurement [9] or by using the geophysical method $[1,9,10]$.

Furthermore, the characteristics of peat or organic soil are also influenced by the electrical conductivity $(\sigma)$ properties and susceptibility magnetic $(\chi \mathrm{m})$ properties. The $\sigma$ properties of the soil are also influenced by organic matter content, water content, and clay content $[11,12]$. The more organic contents in the peat, the higher the $\sigma$ [13-15]. In magnetism, the $\chi \mathrm{m}$ properties of the soil also has a correlation with organic content: $\chi \mathrm{m}$ decreases as organic matter content increases. This is the same as research in eroded areas in Sakatchewan, Canada [16]. In the studies of land conducted by Hanesch and Scholger [17] and Hanesch et.al [18], it was concluded that soil with more organic content had a smaller $\chi_{\mathrm{m}}$. This is the same result as in the study of Hošek et.al [19]. Rothwell and Lindsay [20] charted the Alport More area in the UK in the terms of the relationship between peatland and $\chi \mathrm{m}$ values. Their results indicated that the presence of peat or organic soil was characterized by lower $\chi \mathrm{m}$ values. 
The cluster K-means method is the most effective for clustering, and it can be applied in various studies [21]. The cluster K-means method has been applied to analyze topography and soil data [22], water classification [23], transportation [24], electricity consumption [25-27], tumor areas in the field of medicine [28], and validate the existence of oil palm plantations [29]. K-means clustering determines the landslide boundary in the Three Gorges area in China [30]. The cluster means method divides the segments based on similar data. In this study, it is expected that data collected from one layer will be the same, while the data will differ from other layers. The parameters $\sigma$ and $\chi \mathrm{m}$ are used to analyze and characterize the soil effectively. In this study, K-means clustering determines the boundary peat soil layer based on electrical and magnetism properties.

\section{Materials and Methods}

The study area is located at the Tegal Arum Village, $31 \mathrm{~km}$ from Southeast Banjarmasin in Indonesia. This study was conducted during the dry season in June 2015, and the geographic coordinates of this site are given by $03^{\circ} 25^{\prime} 19.6^{\prime \prime} \mathrm{S}$ and $114^{\circ} 45^{\prime} 55^{\prime \prime} \mathrm{E}$ with an elevation of $50 \mathrm{~m}$ a.s.l (as shown in Figure 1).

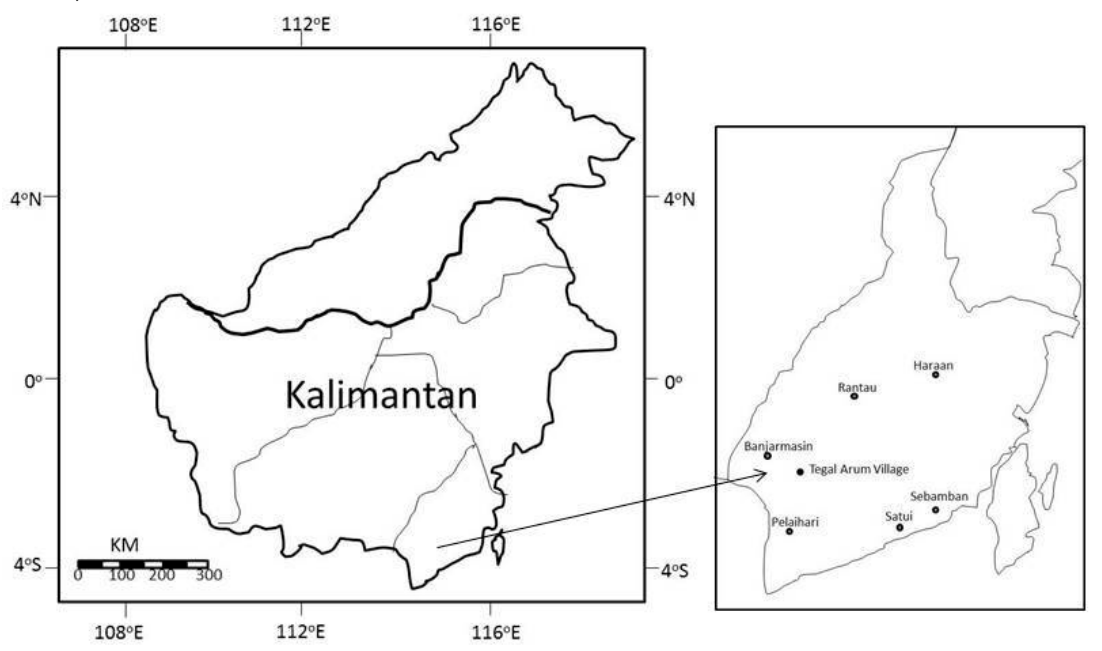

Figure 1. Location of the study area: Tegal Arum Village in South Kalimantan, Indonesia.

\subsection{Soil Samples}

Soil samples were taken from the field using a $4 \mathrm{~cm}$ diameter hand auger. Then, the soils were dug down vertically to $3 \mathrm{~m}$ in depth using the hand auger in $0.5 \mathrm{~m}$ intervals. The hand auger must be cleaned before and after using it so that the samples of soils are not contaminated by another sample. Then, samples were wrapped with aluminum foil before being stored in PVC pipes so that the moisture remains. In the laboratory, $\sigma$ measurements of the samples were conducted per $1 \mathrm{~cm}$ using the EM 50 data logger. For $\chi_{\mathrm{m}}$ measurements, samples were sliced $1 \mathrm{~cm}$ thick and placed in cylindrical plastic holders $(2.5 \mathrm{~cm}$ in diameter, $2.2 \mathrm{~cm}$ in height). The mass of each sample was measured using an OHAUS analytical balance. After that, each sample was measured for mass and then measured for its $\chi_{\mathrm{m}}$ using the Bartington MS2 magnetic susceptibility system (Bartington Instruments Ltd., England) with an MS2B sensor set to a frequency of $470 \mathrm{~Hz}$. The soil samples were analyzed in a chemical laboratory, TekMIRA (Research and Development Center of Mineral and Coal Technology) using loss on ignition LOI measurement with an ASTM-D2974 standard. For the measurement of LOI, the first step was to heat an empty cup then put it into the furnace at 800-900 ${ }^{\circ} \mathrm{C}$ for 30 minutes. Then the cup was inserted into the desiccator for 15 minutes and weighed (weight A). After that, the soil sample $(1 \mathrm{~g})$ was put into a cup and weighed (weight B). Next, the cup with the soil sample was inserted into the furnace at $800-900{ }^{\circ} \mathrm{C}$. After that, the sample was inserted into the desiccator and re-weighed as weight $\mathrm{C}$. The LOI content was calculated using the formula 


$$
\% L O I=\frac{B-C}{B-A} \times 100 \%
$$

Note the sample soil had been dried for 1 hour at $100-110^{\circ} \mathrm{C}$.

\subsection{K-Means Cluster Method}

The cluster method is used in the separation of random data into several clusters based on heterogeneous data. One group must have homogeneous data. There are several types of cluster methods. The K-means method is effective in clustering more than 100 data. The K-means cluster chooses the number of clusters $\mathrm{K}$ randomly and more $\mathrm{K}$ cluster center locations. The distance of each data point to the central data was calculated by finding the smallest distance between each point to each centroid. The new centroid is calculated by finding the smallest distance between input vectors and the centroid vector, and this is repeated until iteration to convergence. The iterate determined the criteria for updating new cluster centers. In maximum iterations, it determined the maximum number of the iterations. Convergence criterion was used to decide when to close the iteration process.

\section{Results and Discussions}

\subsection{Magnetic Susceptibility $\left(\chi_{m}\right)$ and Electrical Conductivity $(\sigma)$ Properties}

The measured $\chi_{\mathrm{m}}$ properties range from -2.4 to $68 \times 10^{-8} \mathrm{~m}^{3} / \mathrm{kg}$, as shown in Figure 2a. The soil from $0-5 \mathrm{~cm}$ depth has the maximum $\chi_{\mathrm{m}}$ properties. There were minimum and negative $\chi_{\mathrm{m}}$ properties at 6 to $147 \mathrm{~cm}$ depth, and soil below $147 \mathrm{~cm}$ had positive $\chi_{\mathrm{m}}$ properties. The $\sigma$ properties differ from the $\chi_{\mathrm{m}}$ properties. Up to $185 \mathrm{~cm}$ in depth, there is an increase of the $\sigma$ properties. The $\sigma$ properties were lower at 185-237 cm depth. Below $237 \mathrm{~cm}$ depth there is an increase of the $\sigma$ properties. The boundary layers could not be determined based on the measurement of the properties, so the boundary layers can be determined using cluster method. There were 272 data points for the $\chi_{\mathrm{m}}$ and the $\sigma$ properties because more than 100 data points are needed to use the K-means cluster method effectively.

\subsection{K-Means Cluster Analysis}

The data of the $\chi_{\mathrm{m}}$ and the $\sigma$ properties have large ranges of value (as shown in Figure 2a). To improve the efficiency of the process, the K-means cluster used SPSS analysis and, for this, the data must be normalized. This is shown in Figure 2b. In K-means clustering, the researcher designates the number of clusters. We used two clusters. This means two layers. The first step chose the first centroid for each of the $\chi_{\mathrm{m}}$ and the $\sigma$ properties in minimum and maximum values (shown in Table 1). Table 1 showed that there were two clusters for the $\chi_{\mathrm{m}}$ properties with the minimum values in cluster 1 and maximum values in cluster 2 . For the $\sigma$ properties, the maximum values were in cluster 1 and the minimum in cluster 2 . 


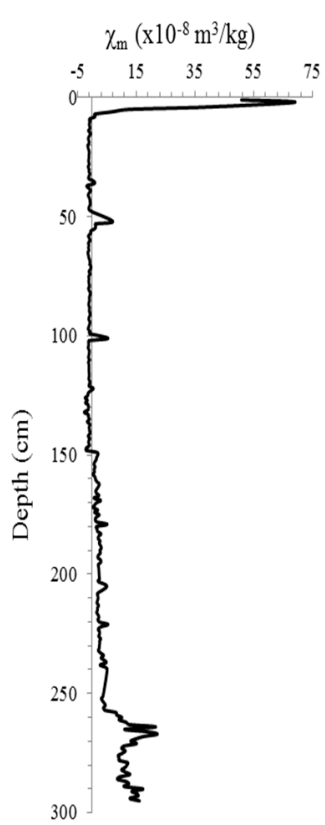

(a)
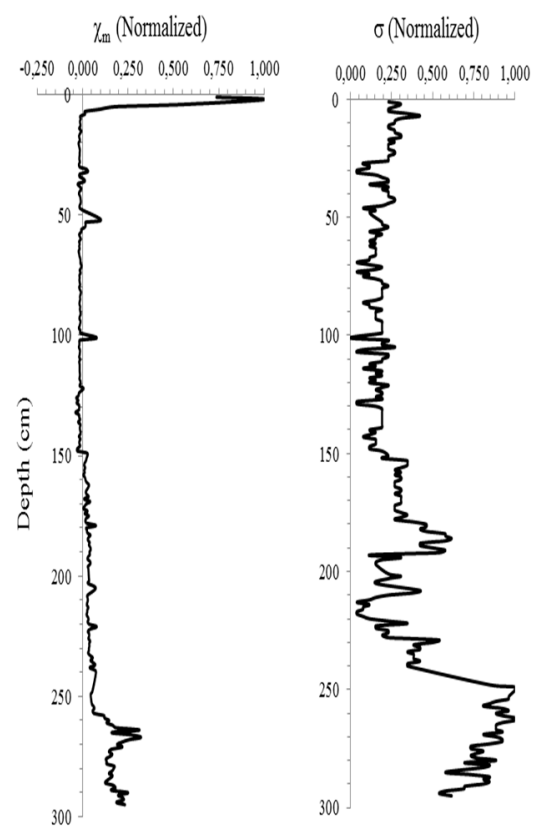

(b)

Figure 2. (a) Magnetic susceptibility $\left(\chi_{\mathrm{m}}\right)$ and electrical conductivity $(\sigma)$ data. $(\mathbf{b})$ Magnetic susceptibility $\left(\chi_{\mathrm{m}}\right)$ and electrical conductivity $(\sigma)$ normalized data.

Table 1. Maximum and minimum centroid.

\begin{tabular}{ccc}
\hline \multicolumn{3}{c}{ Initial Cluster Centers } \\
\hline & Cluster & Cluster \\
\cline { 2 - 3 } & 1 & 2 \\
\hline$\chi \mathrm{m}$ Norm & .045 & 1.000 \\
\hline$\sigma$ Norm & 1.000 & .308 \\
\hline
\end{tabular}

In the second step, the results of the minimum and maximum values from first centroid are re-calculated with each iteration to find new centroid. This analysis determined 15 iterations (as shown in Table 2). The iteration is re-updated automatically when the centroid finds the right centroid for each cluster. The number cluster is determined to be accurate if 15 iterations have the convergent centroid obtaining 0 (zero). Determination of the number cluster is done to analyze the data [30]. The iteration is in 15 iterations; however, the convergent criteria obtains 0-13 iterations. Therefore using two clusters for this data has been appropriated.

Table 2. History of iteration centroid cluster.

\begin{tabular}{ccc}
\hline \multicolumn{3}{c}{ Change in Cluster Centers } \\
\hline Iteration & \multicolumn{1}{c}{1} & \multicolumn{1}{c}{2} \\
\hline 1 & .733 & .839 \\
\hline 2 & .005 & .043 \\
\hline 3 & $2.293 \mathrm{E}-5$ & .001 \\
\hline 4 & $9.596 \mathrm{E}-8$ & $3.550 \mathrm{E}-5$ \\
\hline 5 & $4.015 \mathrm{E}-10$ & $1.014 \mathrm{E}-6$ \\
\hline 6 & $1.680 \mathrm{E}-12$ & $2.898 \mathrm{E}-8$ \\
\hline 7 & $6.895 \mathrm{E}-15$ & $8.279 \mathrm{E}-10$ \\
\hline
\end{tabular}




\begin{tabular}{ccc}
\hline 8 & .000 & $2.365 \mathrm{E}-11$ \\
\hline 9 & .000 & $6.761 \mathrm{E}-13$ \\
\hline 10 & .000 & $1.913 \mathrm{E}-14$ \\
\hline 11 & .000 & $5.796 \mathrm{E}-16$ \\
\hline 12 & .000 & $1.110 \mathrm{E}-16$ \\
\hline 13 & .000 & .000 \\
\hline
\end{tabular}

Results of the K-means cluster iteration showed that the final centroid for each cluster (see Table 3). The number cluster is shown in detail in Appendix A. It can be seen that the data above 248 $\mathrm{cm}$ in depth is in cluster 1 , except for 1 and $2 \mathrm{~cm}$ data which was included into cluster 2 . Cluster 2 is comprised of the data below $248 \mathrm{~cm}$. The results of clustering are two layers of sample soil with the boundary layer at $248 \mathrm{~cm}$ (as shown in Figure 3). Layer 1 is above $248 \mathrm{~cm}$ and has the lowest and negative $\chi_{\mathrm{m}}$ and $\sigma$ properties. Layer 2 is below $248 \mathrm{~cm}$ and has higher and positive $\chi_{\mathrm{m}}$ and $\sigma$ properties.

Table 3. Final centroid in cluster.

\begin{tabular}{ccc}
\hline \multicolumn{3}{c}{ Table 3. Final centroid in cluster. } \\
\hline & \multicolumn{3}{c}{ Cluster } \\
\cline { 2 - 3 } & 1 & 2 \\
\hline$\chi \mathrm{m}$ Norm & .007 & .177 \\
\hline$\sigma$ Norm & .216 & .781 \\
\hline
\end{tabular}

The $\chi_{\mathrm{m}}$ property changes of soil are affected by how much magnetic mineral are in the soil samples. The soils with higher organic matter content or lower magnetic mineral have lower $\chi_{\mathrm{m}}$ properties [17-19]. Layer 1 with lower $\chi_{\mathrm{m}}$ properties is associated with peat soil because lower $\chi_{\mathrm{m}}$ properties tend to show diamagnetic properties, such as in peat [31]. The $\sigma$ properties of peat soil are lower than mineral soil [32] or the resistivity of peat soil is higher than mineral soil [1]. Resistivity properties can be applied in the analysis of the organic content of soil because the $\sigma$ properties are contrary to resistivity [33]. Layer 2, shown in Figure $3 b$, has the higher $\chi_{m}$ and $\sigma$ properties associated with mineral soil.

Measuring the LOI content is a direct method to determine the organic content of soil [34-36]. The LOI measurement is a simple and a cheap method to determine organic content [37]. The soil sample has more than $75 \%$ organic content, and it is associated with peat soil [38]. Wüst et al. [39] categorized the soil sample in Tasek Bera Basin, Malaysia with LOI content of $>45 \%$, which i associated with peat soil. In any case, tropical peat has a higher LOI content and C-organic content [3]. Lupachev et al. [40] showed that the soil in Turbic Cryosol in Russia with humus and organic soil has $8-35 \%$ LOI content, which is associated with mineral soil. The results of this study showed that there are two layers: layer 1 with $86.80 \%$ LOI content and layer 2 with $26.11 \%$ LOI content. According to the results, layer 1 was associated with peat soil and layer 2 with mineral soil. Distribution of the $\sigma$ and the $\chi_{\mathrm{m}}$ properties against depth was shown in Figure 3a, and the layering with the peat layer (represented by a triangle mark) and the mineral layer (represented by a circle mark) is shown in Figure 3b. 


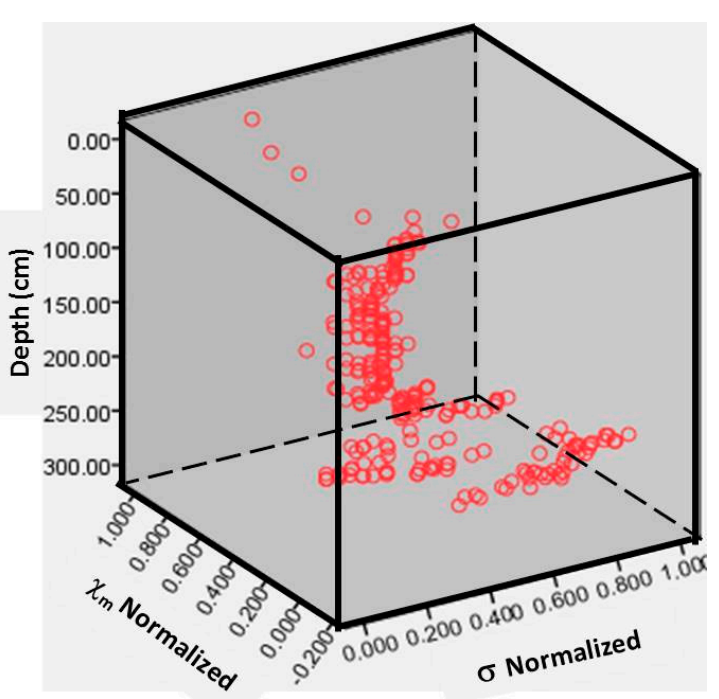

(a)

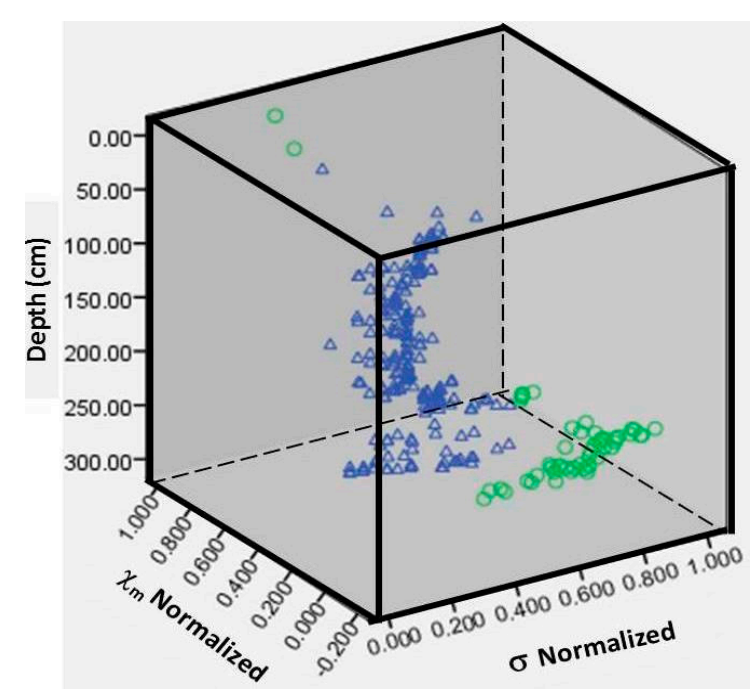

(b)

Figure 3. (a) Magnetic susceptibility and electrical conductivity before clustering. (b) Magnetic susceptibility $\left(\chi_{\mathrm{m}}\right)$ and electrical conductivity $(\sigma)$ with clustering (layer 1 represented by a triangle and layer 2 represented by a circle).

\section{Conclusions}

K-means clustering is more effective for a larger number of data, but the data must be normalized. The K-means cluster is efficient in delineate layering of a soil sample. The soil sample is divided into two layers, namely a peat soil layer and a mineral soil layer. The magnetic susceptibility and electrical conductivity properties of peat soil are lower than mineral soil, and they are appropriated with organic content as shown using the LOI test.

Acknowledgments: The authors would like to thank Tegal Arum village officials in the South Kalimantan, Indonesia for their cooperation and support during the field measurement and The Ministry of Research, Technology and Higher Education of the Republic of Indonesia for the research grant.

Author Contributions: Mimin Iryanti, Satria Bijaksana, Wahyu Srigutomo, and Tedy Setiawan conceived the idea for this study. Mimin Iryanti, Ahmad Aminudin, and Eleonora Agustine prepared the manuscript.

Conflicts of Interest: The authors declare no conflicts of interest. 


\section{Appendix A}

\section{Cluster membership of case numbers}

\begin{tabular}{|c|c|c|c|}
\hline $\begin{array}{l}\text { Case } \\
\text { Number }\end{array}$ & $\begin{array}{l}\text { Depth } \\
(\mathrm{m})\end{array}$ & Cluster & Distance \\
\hline 1 & 1.00 & 2 & .711 \\
\hline 2 & 2.00 & 2 & .874 \\
\hline 3 & 4.00 & 1 & .560 \\
\hline 4 & 5.00 & 1 & .172 \\
\hline 5 & 6.00 & 1 & .122 \\
\hline 6 & 7.00 & 1 & .161 \\
\hline 7 & 8.00 & 1 & .046 \\
\hline 8 & 9.00 & 1 & .024 \\
\hline 9 & 10.00 & 1 & .021 \\
\hline 10 & 11.00 & 1 & .040 \\
\hline 11 & 12.00 & 1 & .039 \\
\hline 12 & 13.00 & 1 & .023 \\
\hline 13 & 14.00 & 1 & .030 \\
\hline 14 & 15.00 & 1 & .049 \\
\hline 15 & 16.00 & 1 & .051 \\
\hline 16 & 17.00 & 1 & .043 \\
\hline 17 & 18.00 & 1 & .028 \\
\hline 18 & 19.00 & 1 & .040 \\
\hline 19 & 20.00 & 1 & .045 \\
\hline 20 & 21.00 & 1 & .044 \\
\hline
\end{tabular}

\begin{tabular}{cccc}
\hline $\begin{array}{l}\text { Case } \\
\text { Number }\end{array}$ & $\begin{array}{l}\text { Depth } \\
(\mathrm{m})\end{array}$ & Cluster & Distance \\
\hline 69 & 73.00 & 1 & .226 \\
\hline 70 & 74.00 & 1 & .149 \\
\hline 71 & 75.00 & 1 & .187 \\
\hline 72 & 76.00 & 1 & .112 \\
\hline 73 & 77.00 & 1 & .075 \\
\hline 74 & 78.00 & 1 & .075 \\
\hline 75 & 79.00 & 1 & .039 \\
\hline 76 & 80.00 & 1 & .076 \\
\hline 77 & 81.00 & 1 & .075 \\
\hline 78 & 82.00 & 1 & .073 \\
\hline 79 & 83.00 & 1 & .074 \\
\hline 80 & 84.00 & 1 & .075 \\
\hline 81 & 85.00 & 1 & .111 \\
\hline 82 & 86.00 & 1 & .187 \\
\hline 83 & 87.00 & 1 & .150 \\
\hline 84 & 88.00 & 1 & .149 \\
\hline 85 & 89.00 & 1 & .075 \\
\hline 86 & 90.00 & 1 & .111 \\
\hline 87 & 91.00 & 1 & .110 \\
\hline 88 & 92.00 & 1 & .111 \\
\hline & & & \\
\hline 75 & 1 \\
\hline 75
\end{tabular}

\begin{tabular}{|c|c|c|c|}
\hline $\begin{array}{l}\text { Case } \\
\text { Number }\end{array}$ & $\begin{array}{l}\text { Depth } \\
\text { (m) }\end{array}$ & Cluster & Distance \\
\hline 137 & 142.00 & 1 & .150 \\
\hline 138 & 143.00 & 1 & .187 \\
\hline 139 & 144.00 & 1 & .112 \\
\hline 140 & 145.00 & 1 & .112 \\
\hline 141 & 146.00 & 1 & .111 \\
\hline 142 & 147.00 & 1 & .153 \\
\hline 143 & 148.00 & 1 & .153 \\
\hline 144 & 149.00 & 1 & .072 \\
\hline 145 & 151.00 & 1 & .034 \\
\hline 146 & 152.00 & 1 & .073 \\
\hline 147 & 153.00 & 1 & .084 \\
\hline 148 & 154.00 & 1 & .084 \\
\hline 149 & 155.00 & 1 & .084 \\
\hline 150 & 156.00 & 1 & .046 \\
\hline 151 & 157.00 & 1 & .007 \\
\hline 152 & 158.00 & 1 & .046 \\
\hline 153 & 159.00 & 1 & .007 \\
\hline 154 & 160.00 & 1 & .046 \\
\hline 155 & 161.00 & 1 & .047 \\
\hline 156 & 162.00 & 1 & .026 \\
\hline
\end{tabular}

\begin{tabular}{|c|c|c|}
\hline $\begin{array}{l}\text { Case } \\
\text { Number }\end{array}$ & $\begin{array}{l}\text { Depth } \\
(\mathrm{m})\end{array}$ & Cluster \\
\hline 205 & 217.00 & 1 \\
\hline 206 & 218.00 & 1 \\
\hline 207 & 219.00 & 1 \\
\hline 208 & 220.00 & 1 \\
\hline 209 & 221.00 & 1 \\
\hline 210 & 222.00 & 1 \\
\hline 211 & 223.00 & 1 \\
\hline 212 & 224.00 & 1 \\
\hline 213 & 225.00 & 1 \\
\hline 214 & 226.00 & 1 \\
\hline 215 & 227.00 & 1 \\
\hline 216 & 228.00 & 1 \\
\hline 217 & 229.00 & 1 \\
\hline 218 & 230.00 & 1 \\
\hline 219 & 231.00 & 1 \\
\hline 220 & 232.00 & 1 \\
\hline 221 & 233.00 & 1 \\
\hline 222 & 234.00 & 1 \\
\hline 223 & 235.00 & 1 \\
\hline 224 & 236.00 & 1 \\
\hline
\end{tabular}




\begin{tabular}{|c|c|c|c|}
\hline $\begin{array}{l}\text { Case } \\
\text { Number }\end{array}$ & $\begin{array}{l}\text { Depth } \\
(\mathrm{m})\end{array}$ & Cluster & Distance \\
\hline 21 & 22.00 & 1 & .028 \\
\hline 22 & 23.00 & 1 & .026 \\
\hline 23 & 24.00 & 1 & .041 \\
\hline 24 & 25.00 & 1 & .041 \\
\hline 25 & 26.00 & 1 & .042 \\
\hline 26 & 27.00 & 1 & .187 \\
\hline 27 & 28.00 & 1 & .150 \\
\hline 28 & 29.00 & 1 & .150 \\
\hline 29 & 30.00 & 1 & .227 \\
\hline 30 & 31.00 & 1 & .226 \\
\hline 31 & 32.00 & 1 & .111 \\
\hline 32 & 33.00 & 1 & .075 \\
\hline 33 & 34.00 & 1 & .042 \\
\hline 34 & 35.00 & 1 & .032 \\
\hline 35 & 36.00 & 1 & .147 \\
\hline 36 & 37.00 & 1 & .048 \\
\hline 37 & 38.00 & 1 & .075 \\
\hline 38 & 39.00 & 1 & .036 \\
\hline 39 & 40.00 & 1 & .040 \\
\hline 40 & 41.00 & 1 & .044 \\
\hline 41 & 42.00 & 1 & .026 \\
\hline 42 & 43.00 & 1 & .023 \\
\hline 43 & 44.00 & 1 & .037 \\
\hline 44 & 45.00 & 1 & .075 \\
\hline
\end{tabular}

\begin{tabular}{|c|c|c|c|}
\hline $\begin{array}{l}\text { Case } \\
\text { Number }\end{array}$ & $\begin{array}{l}\text { Depth } \\
(\mathrm{m})\end{array}$ & Cluster & Distance \\
\hline 89 & 93.00 & 1 & .112 \\
\hline 90 & 94.00 & 1 & .074 \\
\hline 91 & 95.00 & 1 & .074 \\
\hline 92 & 96.00 & 1 & .075 \\
\hline 93 & 97.00 & 1 & .077 \\
\hline 94 & 98.00 & 1 & .074 \\
\hline 95 & 99.00 & 1 & .074 \\
\hline 96 & 101.00 & 1 & .271 \\
\hline 97 & 102.00 & 1 & .041 \\
\hline 98 & 103.00 & 1 & .075 \\
\hline 99 & 104.00 & 1 & .075 \\
\hline 100 & 105.00 & 1 & .031 \\
\hline 101 & 106.00 & 1 & .187 \\
\hline 102 & 107.00 & 1 & .226 \\
\hline 103 & 108.00 & 1 & .041 \\
\hline 104 & 109.00 & 1 & .043 \\
\hline 105 & 110.00 & 1 & .074 \\
\hline 106 & 111.00 & 1 & .076 \\
\hline 107 & 112.00 & 1 & .150 \\
\hline 108 & 113.00 & 1 & .112 \\
\hline 109 & 114.00 & 1 & .187 \\
\hline 110 & 115.00 & 1 & .075 \\
\hline 111 & 116.00 & 1 & .111 \\
\hline 112 & 117.00 & 1 & .075 \\
\hline
\end{tabular}

\begin{tabular}{|c|c|c|c|}
\hline $\begin{array}{l}\text { Case } \\
\text { Number }\end{array}$ & $\begin{array}{l}\text { Depth } \\
(\mathrm{m})\end{array}$ & Cluster & Distance \\
\hline 157 & 163.00 & 1 & .023 \\
\hline 158 & 164.00 & 1 & .016 \\
\hline 159 & 165.00 & 1 & .046 \\
\hline 160 & 166.00 & 1 & .047 \\
\hline 161 & 167.00 & 1 & .024 \\
\hline 162 & 168.00 & 1 & .046 \\
\hline 163 & 169.00 & 1 & .056 \\
\hline 164 & 170.00 & 1 & .047 \\
\hline 165 & 171.00 & 1 & .046 \\
\hline 166 & 172.00 & 1 & .009 \\
\hline 167 & 173.00 & 1 & .019 \\
\hline 168 & 174.00 & 1 & .007 \\
\hline 169 & 175.00 & 1 & .052 \\
\hline 170 & 176.00 & 1 & .084 \\
\hline 171 & 177.00 & 1 & .046 \\
\hline 172 & 178.00 & 1 & .014 \\
\hline 173 & 179.00 & 1 & .138 \\
\hline 174 & 180.00 & 1 & .200 \\
\hline 175 & 181.00 & 1 & .200 \\
\hline 176 & 182.00 & 1 & .161 \\
\hline 177 & 183.00 & 1 & .202 \\
\hline 178 & 184.00 & 2 & .264 \\
\hline 179 & 185.00 & 2 & .267 \\
\hline 180 & 186.00 & 2 & .237 \\
\hline
\end{tabular}

\begin{tabular}{|c|c|c|}
\hline $\begin{array}{l}\text { Case } \\
\text { Number }\end{array}$ & $\begin{array}{l}\text { Depth } \\
(\mathrm{m})\end{array}$ & Cluster \\
\hline 225 & 237.00 & 1 \\
\hline 226 & 238.00 & 1 \\
\hline 227 & 239.00 & 1 \\
\hline 228 & 240.00 & 1 \\
\hline 229 & 251.00 & 2 \\
\hline 230 & 252.00 & 2 \\
\hline 231 & 253.00 & 2 \\
\hline 232 & 254.00 & 2 \\
\hline 233 & 255.00 & 2 \\
\hline 234 & 256.00 & 2 \\
\hline 235 & 257.00 & 2 \\
\hline 236 & 258.00 & 2 \\
\hline 237 & 259.00 & 2 \\
\hline 238 & 260.00 & 2 \\
\hline 239 & 261.00 & 2 \\
\hline 240 & 262.00 & 2 \\
\hline 241 & 263.00 & 2 \\
\hline 242 & 264.00 & 2 \\
\hline 243 & 265.00 & 2 \\
\hline 244 & 266.00 & 2 \\
\hline 245 & 267.00 & 2 \\
\hline 246 & 268.00 & 2 \\
\hline 247 & 269.00 & 2 \\
\hline 248 & 270.00 & 2 \\
\hline
\end{tabular}




\begin{tabular}{|c|c|c|c|}
\hline $\begin{array}{l}\text { Case } \\
\text { Number }\end{array}$ & $\begin{array}{l}\text { Depth } \\
(\mathrm{m})\end{array}$ & Cluster & Distance \\
\hline 45 & 46.00 & 1 & .187 \\
\hline 46 & 47.00 & 1 & .109 \\
\hline 47 & 48.00 & 1 & .148 \\
\hline 48 & 52.00 & 1 & .071 \\
\hline 49 & 53.00 & 1 & .071 \\
\hline 50 & 54.00 & 1 & .032 \\
\hline 51 & 55.00 & 1 & .070 \\
\hline 52 & 56.00 & 1 & .148 \\
\hline 53 & 57.00 & 1 & .072 \\
\hline 54 & 58.00 & 1 & .112 \\
\hline 55 & 59.00 & 1 & .111 \\
\hline 56 & 60.00 & 1 & .149 \\
\hline 57 & 61.00 & 1 & .112 \\
\hline 58 & 62.00 & 1 & .150 \\
\hline 59 & 63.00 & 1 & .112 \\
\hline 60 & 64.00 & 1 & .112 \\
\hline 61 & 65.00 & 1 & .113 \\
\hline 62 & 66.00 & 1 & .112 \\
\hline 63 & 67.00 & 1 & .150 \\
\hline 64 & 68.00 & 1 & .149 \\
\hline 65 & 69.00 & 1 & .225 \\
\hline 66 & 70.00 & 1 & .149 \\
\hline 67 & 71.00 & 1 & .072 \\
\hline 68 & 72.00 & 1 & .110 \\
\hline
\end{tabular}

\begin{tabular}{|c|c|c|c|}
\hline $\begin{array}{l}\text { Case } \\
\text { Number }\end{array}$ & $\begin{array}{l}\text { Depth } \\
(\mathrm{m})\end{array}$ & Cluster & Distance \\
\hline 113 & 118.00 & 1 & .150 \\
\hline 114 & 119.00 & 1 & .111 \\
\hline 115 & 120.00 & 1 & .149 \\
\hline 116 & 121.00 & 1 & .041 \\
\hline 117 & 122.00 & 1 & .071 \\
\hline 118 & 123.00 & 1 & .110 \\
\hline 119 & 124.00 & 1 & .077 \\
\hline 120 & 125.00 & 1 & .077 \\
\hline 121 & 126.00 & 1 & .117 \\
\hline 122 & 127.00 & 1 & .078 \\
\hline 123 & 128.00 & 1 & .229 \\
\hline 124 & 129.00 & 1 & .226 \\
\hline 125 & 130.00 & 1 & .112 \\
\hline 126 & 131.00 & 1 & .077 \\
\hline 127 & 132.00 & 1 & .086 \\
\hline 128 & 133.00 & 1 & .076 \\
\hline 129 & 134.00 & 1 & .076 \\
\hline 130 & 135.00 & 1 & .074 \\
\hline 131 & 136.00 & 1 & .079 \\
\hline 132 & 137.00 & 1 & .074 \\
\hline 133 & 138.00 & 1 & .075 \\
\hline 134 & 139.00 & 1 & .075 \\
\hline 135 & 140.00 & 1 & .149 \\
\hline 136 & 141.00 & 1 & .111 \\
\hline
\end{tabular}

\begin{tabular}{|c|c|c|c|}
\hline $\begin{array}{l}\text { Case } \\
\text { Number }\end{array}$ & $\begin{array}{l}\text { Depth } \\
(\mathrm{m})\end{array}$ & Cluster & Distance \\
\hline 181 & 187.00 & 2 & .262 \\
\hline 182 & 188.00 & 1 & .164 \\
\hline 183 & 189.00 & 1 & .164 \\
\hline 184 & 190.00 & 1 & .239 \\
\hline 185 & 191.00 & 2 & .257 \\
\hline 186 & 192.00 & 1 & .276 \\
\hline 187 & 193.00 & 1 & .148 \\
\hline 188 & 194.00 & 1 & .056 \\
\hline 189 & 195.00 & 1 & .077 \\
\hline 190 & 196.00 & 1 & .110 \\
\hline 191 & 197.00 & 1 & .111 \\
\hline 192 & 201.00 & 1 & .040 \\
\hline 193 & 202.00 & 1 & .052 \\
\hline 194 & 203.00 & 1 & .037 \\
\hline 195 & 205.00 & 1 & .125 \\
\hline 196 & 208.00 & 1 & .161 \\
\hline 197 & 209.00 & 1 & .124 \\
\hline 198 & 210.00 & 1 & .037 \\
\hline 199 & 211.00 & 1 & .110 \\
\hline 200 & 212.00 & 1 & .148 \\
\hline 201 & 213.00 & 1 & .225 \\
\hline 202 & 214.00 & 1 & .148 \\
\hline 203 & 215.00 & 1 & .186 \\
\hline 204 & 216.00 & 1 & .186 \\
\hline
\end{tabular}

\begin{tabular}{|c|c|c|}
\hline $\begin{array}{l}\text { Case } \\
\text { Number }\end{array}$ & $\begin{array}{l}\text { Depth } \\
(\mathrm{m})\end{array}$ & Cluster \\
\hline 249 & 271.00 & 2 \\
\hline 250 & 272.00 & 2 \\
\hline 251 & 273.00 & 2 \\
\hline 252 & 274.00 & 2 \\
\hline 253 & 275.00 & 2 \\
\hline 254 & 276.00 & 2 \\
\hline 255 & 277.00 & 2 \\
\hline 256 & 278.00 & 2 \\
\hline 257 & 279.00 & 2 \\
\hline 258 & 280.00 & 2 \\
\hline 259 & 281.00 & 2 \\
\hline 260 & 282.00 & 2 \\
\hline 261 & 283.00 & 2 \\
\hline 262 & 285.00 & 2 \\
\hline 263 & 286.00 & 2 \\
\hline 264 & 287.00 & 2 \\
\hline 265 & 288.00 & 2 \\
\hline 266 & 289.00 & 2 \\
\hline 267 & 290.00 & 2 \\
\hline 268 & 291.00 & 2 \\
\hline 269 & 292.00 & 2 \\
\hline 270 & 293.00 & 2 \\
\hline 271 & 294.00 & 2 \\
\hline 272 & 295.00 & 2 \\
\hline
\end{tabular}




\section{References}

1. Comas, X.; Terry, N.; Slater, L.; Warrren, M.; Kolka, R.; Kristiyono, A.; Sudiana, N.; Nurjaman, D.; Darusman, T. Imaging tripocal peatland in Indonesia using ground-penetrating radar (GPR) and electrical reisitivity imaging (ERI): implications for carbon stock estimates and peat soil characterization. Biogeosciences. 2015, 12, 2995-3007. DOI:10.5194/bg-12-2995-2015

2. Warren, M.W.; Kauffman, J.B; Murdiyarso, D.; Anshari, G.; Hergoualc, K.; Kurnianto, S.; Purbopuspito, J.; Gusmayanti, E., Afifudin, M.; Rahajoe.; Alhamd. J.; Limin, S.; Iswandi. S. A csot-efficient method to assess carbon stocks in tropical peat soil. Biogeosciences. 2012, 9, 4477-4485. DOI:10.5194/bg-9-4477-2012

3. Anshari, G.Z.; Aifudin, M.; Nuriman, M., Gusmayanti, E., Arianie, L., Susana, R., Nusantara, R.W.; Sugardjito, J., Rafiastanto, A. Drainage and land use impacts in changers in selected peat properties and peat degradation in west kalimantan province, indonesia. Biogeosciences. 2010, 7, 3403-3419. DOI: 10.5194/bg-7-3403-2010.

4. Jaenicke, J.; Rieley, J. O.; Mott, C., Kimman, P.; Siegert, F. Determination of the Amount of Carbon Stored in Indonesia Peatlands. Geoderma. 2008, 147, 151-158. DOI:10.1016/j.geoderma.2008.08.008

5. Shimada, S.; Takahashi, H.; Haraguchi, A.; Kaneko, M. The Carbon Content Characteristics Of Tropical Peats in Central Kalimantan, Indonesia: Estimating Their Spatial Variability in Density. Biogeochemistry. 2001, 53, 3, 249-267

6. Farmer, J.; Matthews, R.; Smith, P.; Langan, C.; Hergoualc'h, K.; Verchot, L.; Smith, Jo.U. Comparison of method for quantifying soil carbon in tropical peats. Geoderma. 2014, 214-215,177-183. DOI: 10.1016/j.geoderma.2013.09.013

7. Hadi, A.; Inubushi, K.; Furukawa, Y.; Purnomo, E.; Rasmadi, M.; Tsuruta, H. Greenhouse gas emissions from tropical peatlands of Kalimantan, Indonesia. Nutr Cycl Agroecosys. 2005, 71: $73-80$. DOI:10.1007/s10705-004-0380-2

8. Page, S. E.; Rieley, J.O.; Banks, C.J. Global and regional importance of the tropical peatland carbon pool. Glob Change Biol. 2011, 17, 798-818. DOI: 10.1111/j.1365-2486.2010.02279.x

9. Slater, L.D.; Binley, A.; Revee, A. Solute Transport Processes In Peatlnd Inferred From Electrical Imaging. Symposium On The Application Of Geophysics To Engineering And Environmental Problem, 2003, 676-686. Access on 20 January 2013.

10. Slater, L.D.; Reeve, A. Case History: Investigating Peatland Stratigraphy and Hydrology Using Integrated Electrical Geophysics. Geophysics. 2002, 67, 2, 365-378.

11. McCutcheon, M.C.; Farahani, H.J.; Stednick, J.D.; Buchleiter, G.W.; Green, T.R. Effect of soil water on apparent soil electrical conductivity and texture relationships in a dryland field. Biosyst Eng. 2006, 94, 19-32. DOI:10.1016/j.biosystemseng.2006.01.002

12. Corwin, D.L.; Lesch, S.M. Apparent Soil Electrical Conductivity Measurement in Agriculture. Comput Electron Agr. 2005, 46, 11-43. DOI:10.1016/j.compag.2004.10.005

13. Persson, M.; Uvo, C.B. Estimating Soil Solution Electrical Conductivity from Time Domain Reflectometry Measurement Using Neutral Networks. J. Hydrol. 2003, 273, 249-256.

14. K. Noborio, -Measurement of Soil Water Content and Electrical Conductivity by Time Domain Reflectometry: a Review. Comput Electron Agr. 2001, 31, 213-237

15. Ahire, D.V.; Chaudhari, P.R.; Ahire, V.D. Correlations of Electrical Conductivity and Dielectric Constant with Physico-Chemical Properties of Black Soils. International Journal of Scientific and Research Publications. 2013, 3, 1-16

16. De Jong, E.; Nestor, P.A.; Pennock, D.J. The use of magnetic susceptibility to measure long-term soil redistribution. Catena. 1998, 32, 23-35.

17. Hanesch, M.; Scholger, R. The influence of soil type on the magnetic susceptibility measured throughout soil profiles. Geophysic J. Int. 2005, 161, 50-56. DOI: 10.1111/j.1365-246X.2005.02577.x

18. Hanesch, M.; Rantitsch, G.; Hemetsberger, S.; Scholger, R. Lithological and pedological influence on the magnetic susceptibility of soil: their consideration in magnetic pollution mapping. Sci. Total Environ. 2007, 382, 351-363. DOI:10.1016/j.scitotenv.2007.04.007

19. Hošek, J.; Hambach, U.; Lisá, L.; Grygar, T.M.; Horáček, I.; Meszner, S.; Knésl, I. An integrated rock-magnetic and geochemical approach to loess/paleosol sequences from Bohemia and Moravia (Czech Republic): Implicaton for the upper pleistocene paleoenvironment in central Europe. Palaeogeogr Palaeocl. 2015, 418, 344-358. DOI: 10.1016/j.palaeo.2014.11.024 
20. Rothwell, J.J.; Lindsay, J.B. Mapping contemporary magnetic mineral concentrations in peat soils using fine-resolution digital terrain data. Catena. 2007, 70, 465-474. DOI:10.1016/j.catena.2006.12.001

21. Alsabti, K.; Ranka, S.; Singh, V. An efficient K-means clustering algorithm. Electrical Engineering and computer science. 1997, 43.

22. Arkel, Z.J.V.; Kaleita, A.L. Identifying sampling locations for field-scale soil moisture estimation using K-means clustering. Agricultural and Biosystem Engineering Publication. 2014, 7050-7057.

23. Zou, H.; Zou, Z.; Wang, X. An enhanced K-means algorithm for water quality analysis of the Haihe river in China. Int. J. Environ. Res. Public Health. 2015, 12, 14400-14413. DOI: 10.3390/ijerph121114400

24. Zhou, X.; Gu, J.; Shen, S.; Ma, H.; Miao, F.; Zhang, H.; Gong, H. An Automatic K-means clustering algorithm of GPS data combining a novel niche genetic algorithm with noise and density. ISPRS Int. J. Geo-Inf. 2017, 6, 392. DOI: 10.3390/ijgi6120392

25. Amri, Y.; fadhilah, A.L.; Fatmawati,; Setiani, N.; Rani, S. Analysis clustering of electricity usage profile using K-means algorithm. IOP Conf. Series: Material science and engineering. 2016, 105, 012020. DOI: 10.1080/1757-899x/105/1/012020.

26. Liu, L. Cluster analysis of electrical behavior. Journal of computer and communication. 2015, 3, 88-93. DOI: 10.4236/jcc.2015.35011

27. Lòpez, J.J.; Aguado, J.A; Martín, F.; Muñoz, F.; Rodríguez, A.; Ruiz, J.E. Hopfield-K-means clustering algorithm: a proposal for the segmentation of electricity customers. Electr. Pow. Syst. Res. 2011, 81, 716-724. DOI:10.1016/j.epsr.2010.10.036

28. Hugos, Y.B.; Minh, V.H.; Khawaldeh, S.; Pervaiz, U.; Allef, T.A. Fast PET scan tumor segmentation using superpixels, principal component analysis and K-means clustering. Method and Protocols, 2018, 1, 7. DOI: 10.3390/mps1010007

29. Li, L.; Dong, J.; Tenku, S.N.; Xiao, X. Mapping oil palm plantations in cameron using PALSAR 50-m othorectified mosaic Images. Remote Sens, 2015, 7, 1206-1225. DOI: 10.3390/rs70201260

30. Wang, Q.; Wang, Y.; Niu, R.; Peng, L. Integration of Information Theory, K-Means Cluster Analysis and the Logistic Regression Model for Landslide Susceptibility Mapping in the Three Gorges Area, China. Remote Sens. 2017, 9, 938-954. DOI:10.3390/rs9090938

31. Dearing, J.A. Environmental Magnetic Susceptibility, Using the Bartington MS2 System. British Library Cataloguing in Publication Data, 1999, 54p

32. Theimer, B.D.; Nobes, D.C.; Warner, B.G. A Study of The Geoelectrocal Properties of Peatlands and Their Influence on Ground Penetrating Radar Surveying. Geophys Prospect. 1994, 42, 179-209.

33. Iryanti, M.; Srigutomo, W.; Bijaksana, S.; Setiawan, T. Combined DC Resistivity survey and electric conductivity-dielectric permittivity measurement at sag pond near Lembang fault, West Java, Indonesia. Journal of Physics: Conference Series, 2016, 739, 012079. DOI: 10.1088/1742-6596/739/1/012079

34. Sutherland, R.A. Loss-on -ignition estimates of organic matter and relationships to organic carbon in fluvial bed sediments. Hydrobiologia. 1998, 389,153-167

35. Huang, P.T.; Patel, M.; Santagata, M.C.; Bobet, A. Classification of organic soil, Final report FHWA/IN/JTRP-2008/2, 2009, access on 14 April 2016.

36. Howayek, A.E.; Bobet, A.; Dawood, S.; Ferdon, A.; Santagata, M.; Siddiki, N.Z. Project implementation: Classification of organic soils and classification of marls-training of Indot personnel, Report FHWA/IN/JTRP/-2012/22, 2012, access on 14 April 2016

37. Salehi, M.H.; Beni, O.H.; Harchegani, H.B.; Borujeni, L.E.; Motaghian, H.R. Refining soil organic matter determination by Loss-on-Ignition. Pedosphere. 2011, 21, 473-482

38. Zulkifley, M.T.M.; Fatt Ng, T.; Raj, J.K.; Hashim, R.; Ghani, A.; Shuib, M.K.; Ashraf, M.A. Definitions and engineering classification of tropical lowland peats. Bull Eng Geol Environ. 2013, 72, 547-553. DOI: 10.1007/s10064-013-0520-5.

39. Wüst, R.A.J.; Bustin, R.M.; Lavkulich, L.M. New classification systems for tropical organic-rich deposits based on studies of the Tasek Bera Basin, Malaysia. Catena, 2003, 53, 133-163. DOI:10.1016/S0341-8162(03)00022-5

40. Lupachev, A.; Abakumov, E.; Gubin, S. The Influence of Cryogenic Mass Exchange on the Composition and Stabilization Rate of Soil Organic Matter in Cryosols of the Kolyma Lowland (North Yakutia, Russia). Geosciences. 2017, 7, 24-35. DOI:10.3390/geosciences7020024 